\title{
Evaluation of Formants of Cityscape Identity using Fractal Analysis (Kaunas Case)
}

\author{
Ingrida Povilaitienè, Jūratė Kamičaitytė-Virbašienè, Kęstutis Zaleckis \\ Kaunas University of Technology, Kaunas, Lithuania
}

\begin{abstract}
Cityscape identity might be objective and subjective. Still, it is more often analysed from person's perspective, and analysis of urban fabric itself is not considered sufficiently. Thus, this research aims to find out if fractal analysis method could be used to fill that gap. Kaunas city was chosen for the case study. The research was conducted in three stages: qualitative assessment (designation of the zones with different semantic load in Kaunas), quantitative assessment (calculation of fractal indexes of panoramic and streetscape views from previously established zones), and comparison of these approaches. To sum up, the research confirmed that there is a relationship between the results of different approaches. Thus, fractal analysis could be used as one of the tools for quantitative assessment of cityscape identity.
\end{abstract}

Keywords - Assessment, cityscape identity, fractal analysis, Kaunas, semantic load.

\section{INTRODUCTION}

International integration is inevitable. It means not only a faster technological advance but also a possible threat to the unique identities. Concerns about the preservation of historical sites as symbols of the past were already raised in the middle of the 20th century, and it was the beginning of the World Heritage Movement [1]-[3]. However, the preservation of historical sites is not enough for today's cities - cities, which should be alive and evolving. Even though, current sustainable urban planning and design emphasizes balanced development taking into consideration not only environmental, economic, but also sociocultural and aesthetic aspects [4]-[6], it is still an open question how to solve the complex issue of city identity. In general, city is a complex phenomenon comprising people and social, economic, ecological and cultural relations. As architects and urban planners mainly deal with physical environment, it is more accurate to use the cityscape term here. The cityscape identity is still a dual concept. One way of environment identification might be a simple inventory and analysis of its tangible elements and their features, but this physical environment is perceived visually by the observer and "there is no inherent identity to places: this is constructed by human behaviour in reaction to places" [7]. Thus, authors define cityscape identity as a synthesis of subjective identity (determined by the emotional and psychophysiological mechanisms of human beings) and objective identity (determined by physical properties and characteristics of the tangible environment). There are several approaches in the scientific literature how to evaluate different aspects of the cityscape identity [8]. Still, so far urban-related identity is more often analysed from person's perspective. Meanwhile, the analysis of urban fabric itself is not considered sufficiently. Therefore, this research aims to fill that gap by employing method of fractal analysis. Other researchers have successfully used this method to evaluate the complexity and variety of the cityscape [9], [10]. Thus, it could presumably be one of the tools for quantitative assessment of cityscape identity as well.

\section{Methodology}

Kaunas city was chosen for a case study. It is the second metropolitan city of Lithuania, a large centre of industry, culture, technological and scientific potential. Kaunas is the first level centre in the urban framework of Lithuania. It is a city of state and transnational (European) scale, corresponding to the characteristics of agglomerated metropolitan centres.

The research was conducted in three following stages:

- Qualitative assessment (subjective facet of cityscape identity). Theories of semiotics and cultural-historical artefacts [11], [12] were the basis for this assessment. M. Cole [11] claims that, part of the objects or things used to fulfil specific utilitarian human needs become cultural symbols due to the caused cultural associations. In this case, Kaunas can be seen as a specific spatial cultural text that is re-read, interpreted and supplemented by each generation. According to the theories of culturology, symbols of cultural texts consist of four groups: natural, functional, iconic and conventional. Such types of symbols were distinguished in Kaunas city [12] and zones with different semantic load were designated by the spatial distribution of these symbols.

- Quantitative assessment (objective facet of cityscape identity). Both cities and fractals possess certain irregularity, chaos, abundance of scales, self-similarity in different scales and porosity. Taking into account these underlying characteristics, city structure is more often modelled as a fractal [13], [14]. Fractal index is also used for evaluation of qualitative features in urban territories (e.g. comparing the character of places [9] or evaluation of cityscape complexity, and variety [10]). Furthermore, fractal analysis can reveal qualitative characteristics of the environment, based on theories that support the concept of spatial determinism - functional-compositional centre and sequence of scales by N. A. Salingaros [15], [16] and space syntax (space as catalyst of functions) by B. Hillier [17]. Therefore, we hypothetically state that establishing of fractal indexes of zones with different semantic load in Kaunas city could be helpful for further development of cityscape identity, especially in the areas, where the formants of identity are lacking. "Fractal Analysis System" software 
TABLE I

Pre-processing of Oiginal Digital Colour Images [Authors of the Article]

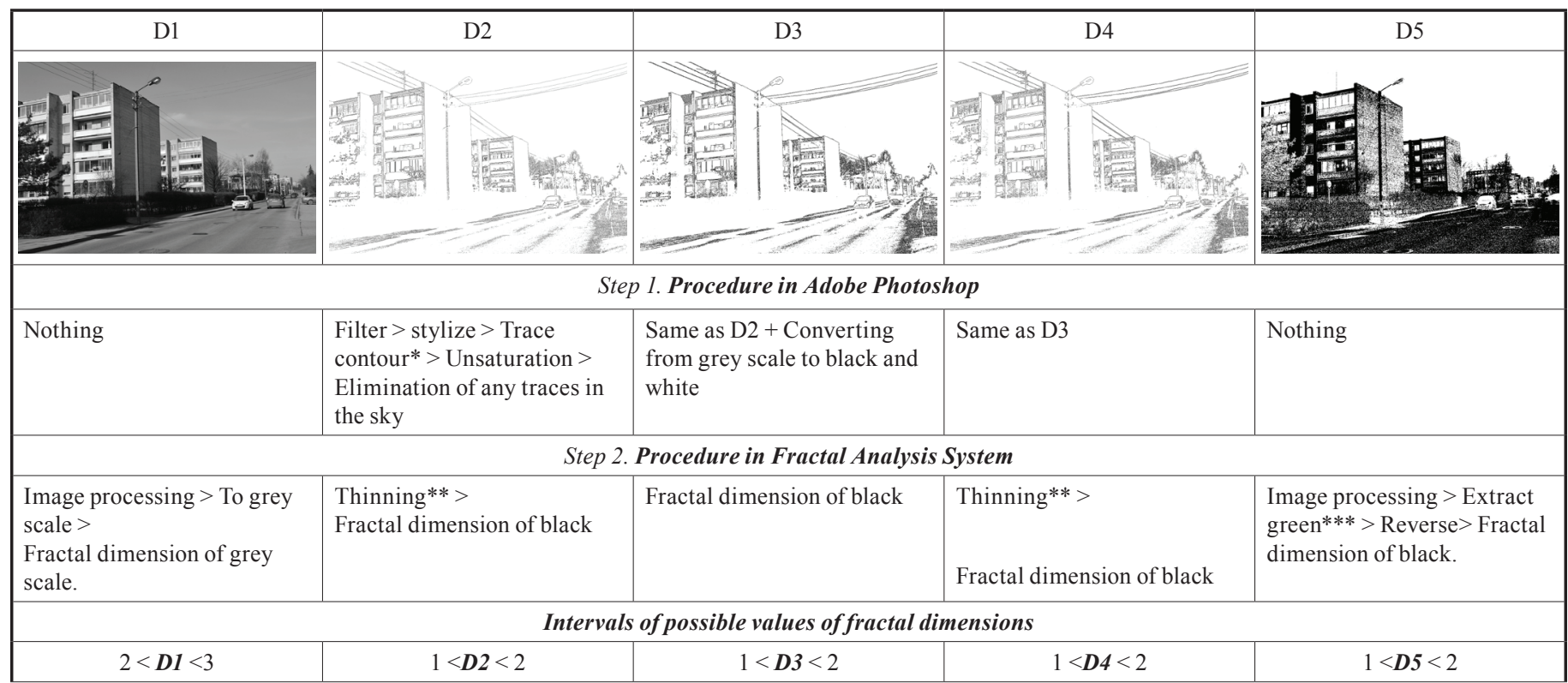

was used and box-counting method was employed to calculate fractal dimensions of panoramic and streetscape images taken from previously established zones of Kaunas city (as our research was rather a pilot experiment testing the methodology, points of photo fixation did not cover all the territory fully, and only the most typical images were analysed). Image pre-processing was done before starting calculations in order to find out how certain modifications might influence the final result (see Table I). Thus, five fractal dimensions $(D 1, D 2, D 3, D 4$ and $D 5)$ were calculated for each of the images.

- Comparison of the first two approaches was done in order to find possible correlations.

\section{Research Results}

\section{A. Kaunas City Zones with Different Semantic Load}

The urban situation of Kaunas was re-evaluated when preparing Kaunas Comprehensive Plan in 2011-2013. Evaluation of city identity formants was a part of an overall survey. There were designated natural, functional, iconic and conventional symbols of Kaunas as city identity formants [12].

Natural symbols are those shape of which is created by nature and content is formed by a community using and adjusting natural objects for its needs in the course of history. The main natural symbols of Kaunas are the following (see Fig. 1): slopes of the river valleys, Oakery, Pazaislis Forest, Nemunas Island, etc.

Functional symbols are those external shape of which reflects present or former function clearly, and the content is formed due to the associations raised by the mentioned function. The main functional symbols of Kaunas are the following (see Fig. 1): Old Town, New Town, Savanoriai Av., Juozapavicius Av., Veiveriai Rd., Raudondvaris Rd., Kaunas Hydropower Plant, Railway Tunnel, Kaunas Fortress, etc.

Iconic symbols are symbols, which by their shape are related to the iconic signs inherent in the culture or city, marking one or other content and comprehensible practically by all representatives of one or other culture. The main iconic symbols of Kaunas are the following (see Fig. 1): Town Hall, Thunder House, Vytautas Church, Resurrection Church, Central Post Office, Museum of War, Pazaislis Monastery, etc.

Conventional symbols are formed on the basis of public agreement. Since both language and other semantic systems are formed on the basis of so-called social agreement and cannot be replaced by one-off act of the will; in the cityscape, such form of agreement can be historical events fixed in the of memory of the public, legends or myths, specific traditions of areas/spaces use. The main conventional symbols of Kaunas are the following (see Fig. 1): Napoleonas Hill, Former Presidency, Aleksotas Aerodrome, Zoo, Botanic Garden, etc.

Part of mentioned symbols overlaps and represents several groups. Some of them concentrate forming the complex of the city text. Such places and symbols are especially important to preserve the identity of the city (see Fig. 1).

The clear distribution of Kaunas city identity formants enables the designation of zones with different semantic load (see Fig. 2). Old Town and New Town in the city central part (marked in red) are identified as the zones with the highest concentration of city identity formants and having the biggest semantic load. The second rank of zones with lower semantic load are historic suburbs (marked in green) which surround Kaunas historic centre. 


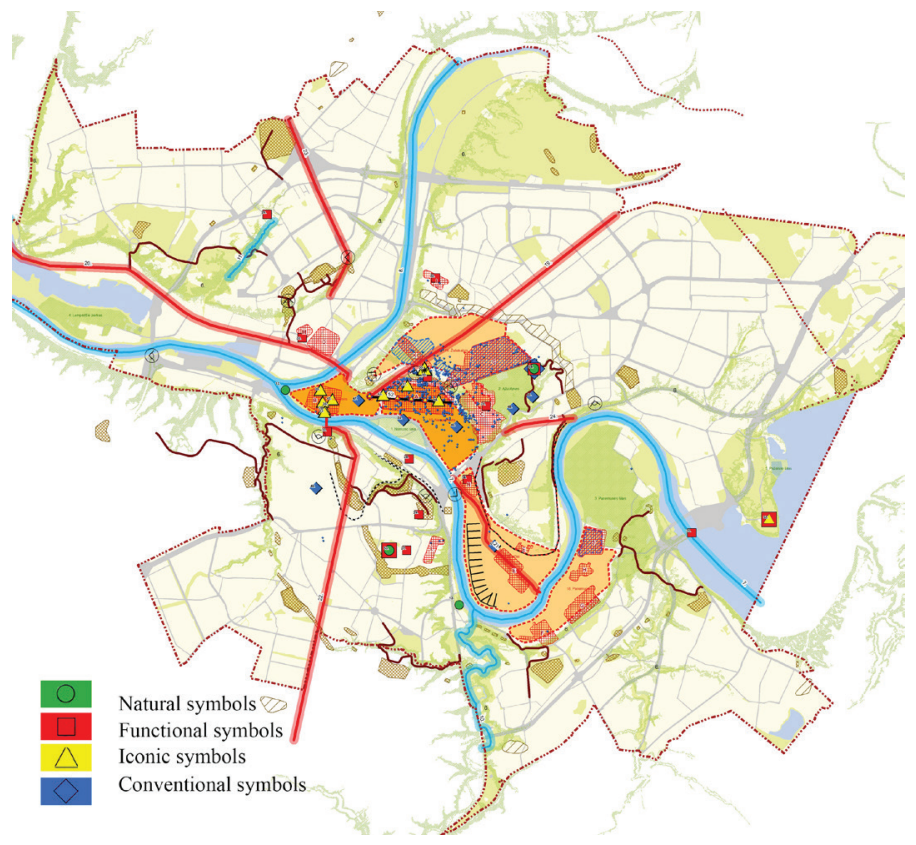

Fig. 1. Distribution of Kaunas city identity formants: natural, functional, iconic and conventional symbols [source: Drawing "Formation of Kaunas City Identity" from Kaunas Municipality Comprehensive Plan 2013-2023, 2014]; [Figure: Authors of the Article].

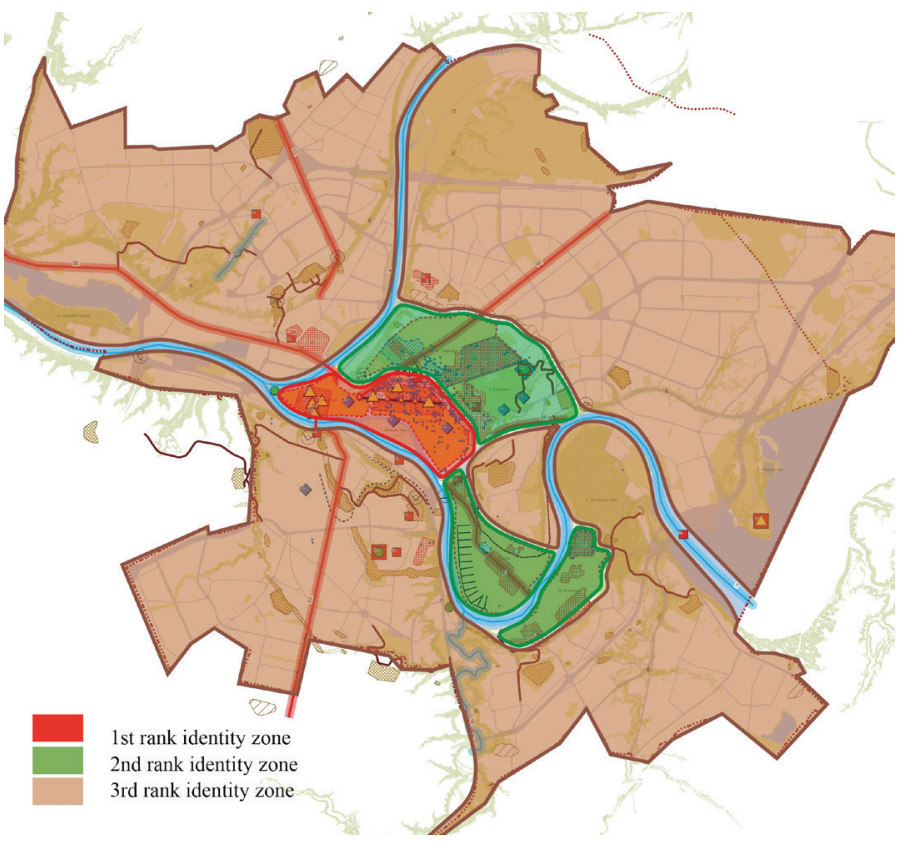

Fig. 2. Distribution of Kaunas city identity formants: scheme of zones with different semantic load [source: Drawing "Formation of Kaunas City Identity" from Kaunas Municipality Comprehensive Plan 2013-2023, 2014]; [Figure: Authors of the Article].

TABLE II

Average Values and Ranking Positions of Fractal Dimension of Panoramic Views [Authors of the Article]

\begin{tabular}{|c|c|c|c|c|c|c|c|c|c|c|c|c|}
\hline \multicolumn{13}{|c|}{ Fractal analysis of panoramic views } \\
\hline & D1 & r1 & D2 & r2 & D3 & r3 & D4 & $\mathbf{r 4}$ & D5 & r5 & $\mathbf{P}$ & $\mathbf{R}$ \\
\hline \multicolumn{13}{|l|}{ First rank } \\
\hline $\begin{array}{l}\text { City centre } \\
\text { (Old Town) }\end{array}$ & 2,3464 & 2 & 1,3851 & 2 & 1,6628 & 2 & 1,6320 & 2 & 1,8359 & 1 & 1,8 & 2 \\
\hline $\begin{array}{l}\text { City centre } \\
\text { (New Town) }\end{array}$ & 2,2566 & 3 & 1,3046 & 3 & 1,5618 & 3 & 1,5303 & 3 & 1,7706 & 3 & 3 & 3 \\
\hline $\begin{array}{l}\text { City centre (untypical spaces in } \\
\text { city centre) }\end{array}$ & 2,1920 & 4 & 1.2138 & 4 & 1,5043 & 4 & 1,4736 & 4 & 1,7398 & 4 & 4 & 4 \\
\hline \multicolumn{13}{|l|}{ Second rank } \\
\hline Historic suburbs & not assessed & & & & & & & & & & & \\
\hline \multicolumn{13}{|l|}{ Third rank } \\
\hline $\begin{array}{l}\text { Residential areas developed } \\
\text { in Soviet times (Dainava) }\end{array}$ & 2,3713 & 1 & 1,3865 & 1 & 1.7147 & 1 & 1.6820 & 1 & 1,8323 & 2 & 1,2 & 1 \\
\hline Single family housing areas & \multicolumn{12}{|l|}{ not assessed } \\
\hline Eastern industrial district & \multicolumn{12}{|l|}{ not assessed } \\
\hline
\end{tabular}

The third rank of zones with very low semantic load or with no identity formants at all are residential areas developed in Soviet times, eastern industrial district, and newly developed single-family housing areas on the city outskirts (marked in brown).
B. Fractal Analysis of the Views from Previously Established Zones. Comparison and Interpretation of Fractal Indexes.

The next step was photo fixation (panoramic and streetscape views) of the zones with different semantic load, but points of photo fixation did not cover whole city. Considering how often 


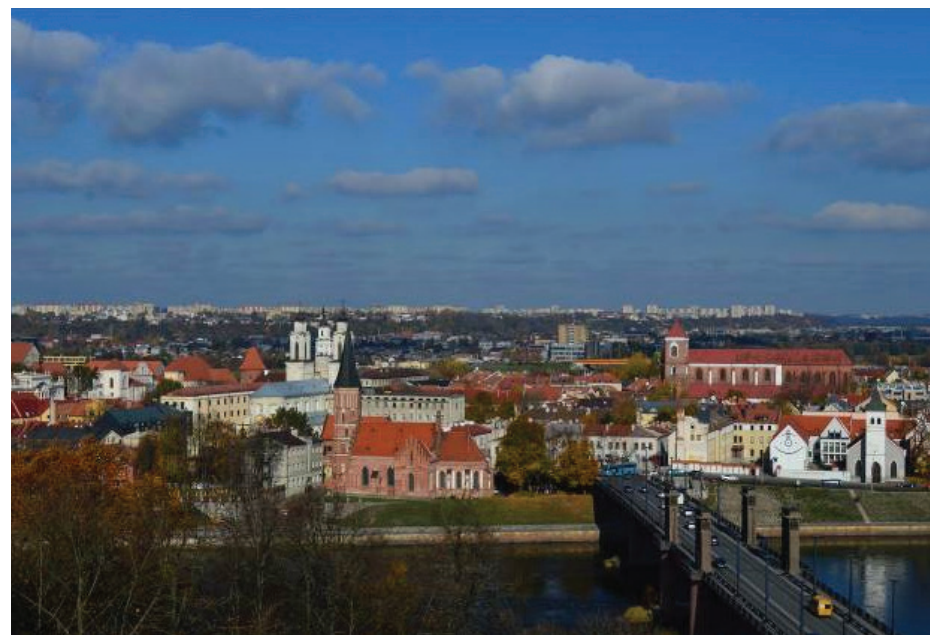

Fig. 3. Typical panoramic view of Old Town area. $(\mathrm{D} 1=2.3331$; D1avera$\mathrm{ge}=2.3464)$ [Photo: Authors of the Article].

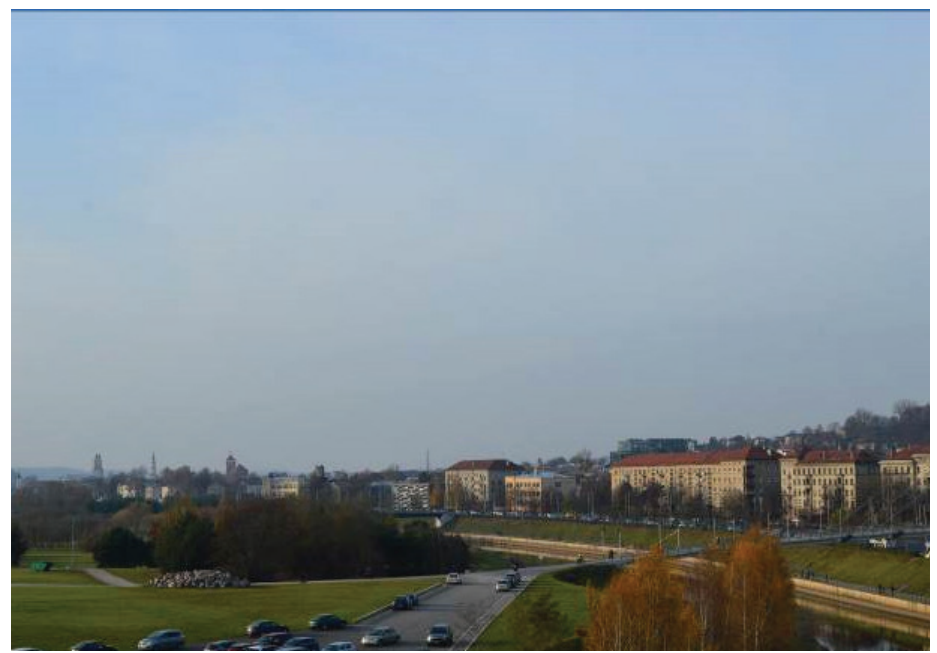

Fig. 5. Untypical spaces in City Centre. $(\mathrm{D} 1=2.1953$; D1 average $=2.1920)$ [Photo: Authors of the Article].

citizens of Kaunas see and experience the city in their everyday life, only the most typical images were captured. The central part of Kaunas is located in the Nemunas river valley and surrounded by its slopes. The panoramic views are well perceived here. Moreover, there are few equipped viewpoints offering amazing vistas of the city centre. Therefore, panoramic views of Old Town and New Town are particularly significant in perception of Kaunas identity. Streetscape views are as much important as panoramic views here, so both of them were analysed in this research. Meanwhile historic suburbs practically always are experienced from the human eye level. It is difficult to find spots opening into panoramic views here, so only streetscape views were analysed in this research. Similar situation is in the newly developed single-family housing areas on the city outskirts, so again just the views from human eye level were analysed. The situation is slightly different in the residential areas developed in Soviet times. Although natural conditions do not provide possibility to

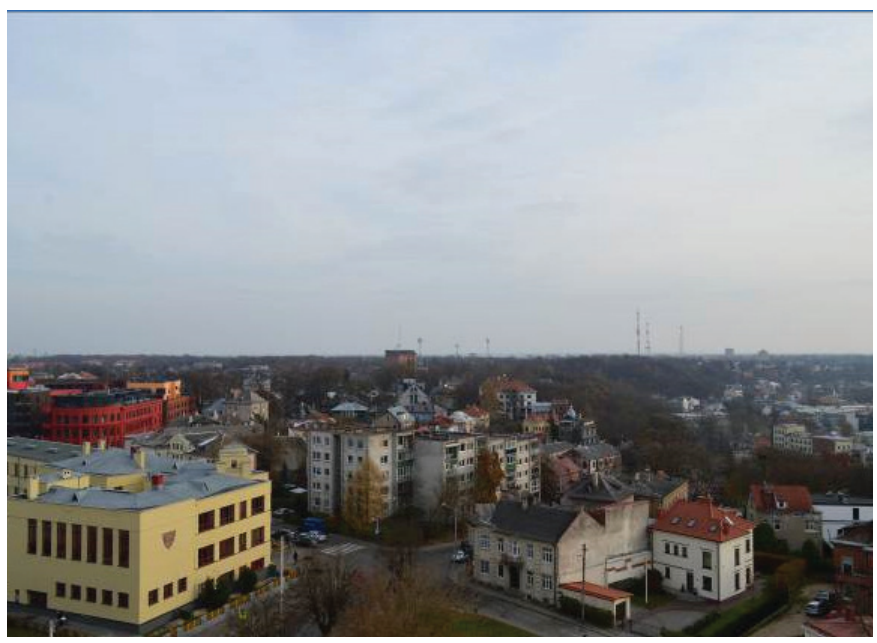

Fig. 4. Typical panoramic view of New Town area. $(D 1=2.2412 ;$ Dlaverage $=2.2566$ ) [Photo: Authors of the Article].

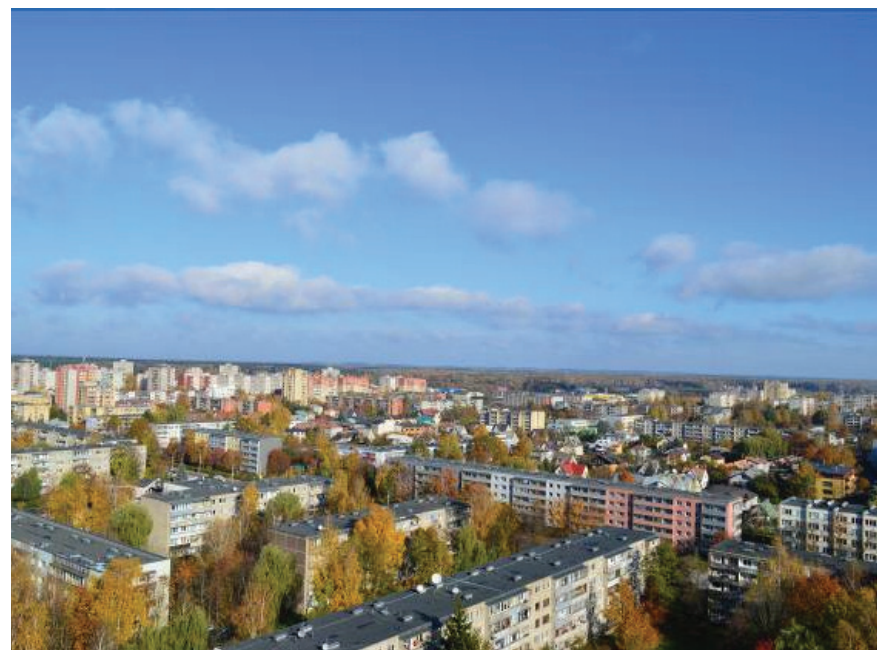

Fig. 6. Typical panoramic view of Dainava district. (D1 = 2.3719; D1avera$\mathrm{ge}=2.3713$ ) [Photo: Authors of the Article].

see a bit wider horizons, yet there are some multi-storey $(9,12$, 13 or even 16 storey) buildings. Residents of these buildings quite often see far reaching vistas. Thus, both panoramic and streetscape views were evaluated here. Finally, we decided not to evaluate the views of one zone-eastern industrial district - at all. It is a very specific, clearly monofunctional district, which no doubt contains very strong and recognizable character. However, regular dwellers and the more so guests of Kaunas city very rarely visit this place. Therefore, this concentrated industrial district was left outside of the scope of the research.

\section{Fractal Analysis of Panoramic Views}

As mentioned before, images were pre-processed in five different ways. Therefore, there are five values of fractal dimension for each image. The average values of fractal dimensions calculated for the panoramic views within different districts are shown in Table II. 
TABLE III

Average Values and Ranking Positions of Fractal Dimension of Streetscape Views [Authors of the Article]

\begin{tabular}{|c|c|c|c|c|c|c|c|c|c|c|c|c|}
\hline \multicolumn{13}{|c|}{ Fractal analysis of streetscape views } \\
\hline & D1 & r1 & D2 & $\mathbf{r 2}$ & D3 & r3 & D4 & r4 & D5 & r5 & $\mathbf{P}$ & $\mathbf{R}$ \\
\hline \multicolumn{13}{|l|}{ First rank } \\
\hline $\begin{array}{l}\text { City centre } \\
\text { (Old Town) }\end{array}$ & 2.3736 & 4 & 1.3445 & 5 & 1.6006 & 6 & 1.5627 & 6 & 1.8549 & 2 & 4,6 & 5 \\
\hline $\begin{array}{l}\text { City centre } \\
\text { (New Town) }\end{array}$ & 2.4301 & 1 & 1.4767 & 1 & 1.6309 & 4 & 1.5915 & 4 & 1.8812 & 1 & 2,2 & 1 \\
\hline $\begin{array}{l}\text { City centre (untypical spaces in } \\
\text { city centre) }\end{array}$ & 2.2851 & 7 & 1.2699 & 7 & 1.5303 & 7 & 1.4906 & 7 & 1.7824 & 7 & 7 & 7 \\
\hline \multicolumn{13}{|l|}{ Second rank } \\
\hline $\begin{array}{l}\text { Historic suburbs } \\
\text { (Zemieji Sanciai) }\end{array}$ & 2.3879 & 2 & 1.3852 & 3 & 1.6660 & 1 & 1.6240 & 1 & 1.8272 & 5 & 2,4 & 2 \\
\hline \multicolumn{13}{|l|}{ Third rank } \\
\hline $\begin{array}{l}\text { Residential areas developed } \\
\text { in Soviet times (Dainava) }\end{array}$ & 2.3842 & 3 & 1.3981 & 2 & 1.6658 & 2 & 1.6213 & 2 & 1.8263 & 6 & 2,6 & 3 \\
\hline $\begin{array}{l}\text { Residential areas developed } \\
\text { in Soviet times (Aukstieji } \\
\text { Sanciai) }\end{array}$ & 2.3461 & 5 & 1.3762 & 4 & 1.6494 & 3 & 1.6091 & 3 & 1.8307 & 4 & 3,8 & 4 \\
\hline $\begin{array}{l}\text { Single family housing areas } \\
\text { (Rokai) }\end{array}$ & 2.3057 & 6 & 1.2863 & 6 & 1.6180 & 5 & 1.5765 & 5 & 1.8342 & 3 & 5 & 6 \\
\hline Eastern industrial district & \multicolumn{12}{|l|}{ not assessed } \\
\hline
\end{tabular}

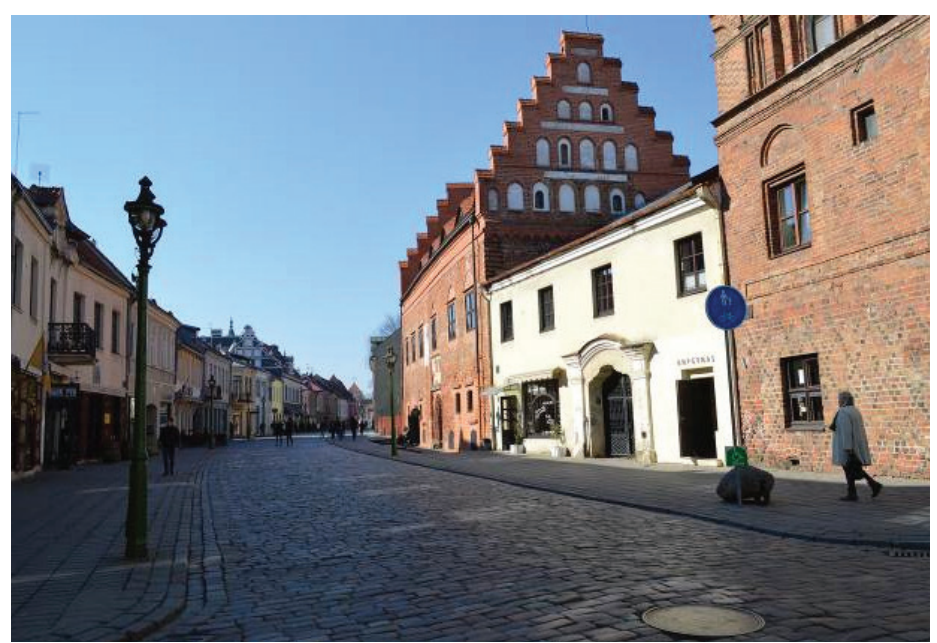

Fig. 7. Typical streetscape view in Old Town area. $(D 1=2.3691 ;$ Dlavera$g e=2.3736$ ) [Photo: Authors of the Article].

Based on the calculated values of fractal dimension, the most typical panoramic views of different districts were selected (see Figs. 3-6, where D1 is fractal dimension of a certain view captured in the photo; Dlaverage is an average value of fractal dimensions in the certain district).

The results of fractal analysis of panoramic views showed that calculated values of fractal dimensions vary among zones with different semantic load (see Table II) depending on certain key

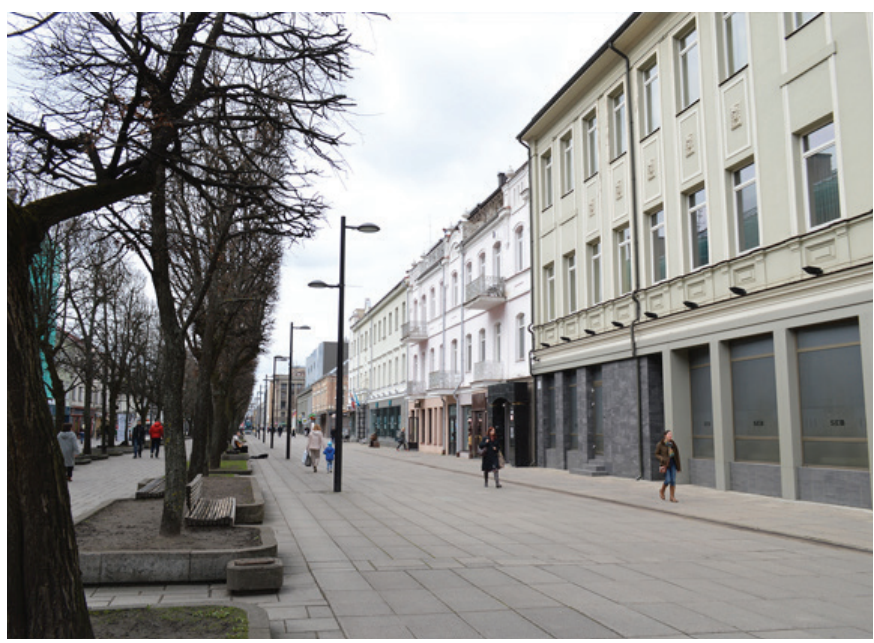

Fig. 8. Typical streetscape view in New Town area. $(D 1=2.4401 ;$ Dlavera$g e=2.4301)$ [Photo: Authors of the Article].

factors. Firstly, Dainava district had the highest fractal dimension due to quite regular building up and abundant vegetation. Old Town district was in the second ranking position because there is slightly less vegetation, but historical architecture increases the complexity of the panoramic view. New Town took even lower place because it lacks greenery and the architecture of buildings is simpler. Finally, the lowest fractal dimension was calculated for the untypical spaces in the city centre, where empty 


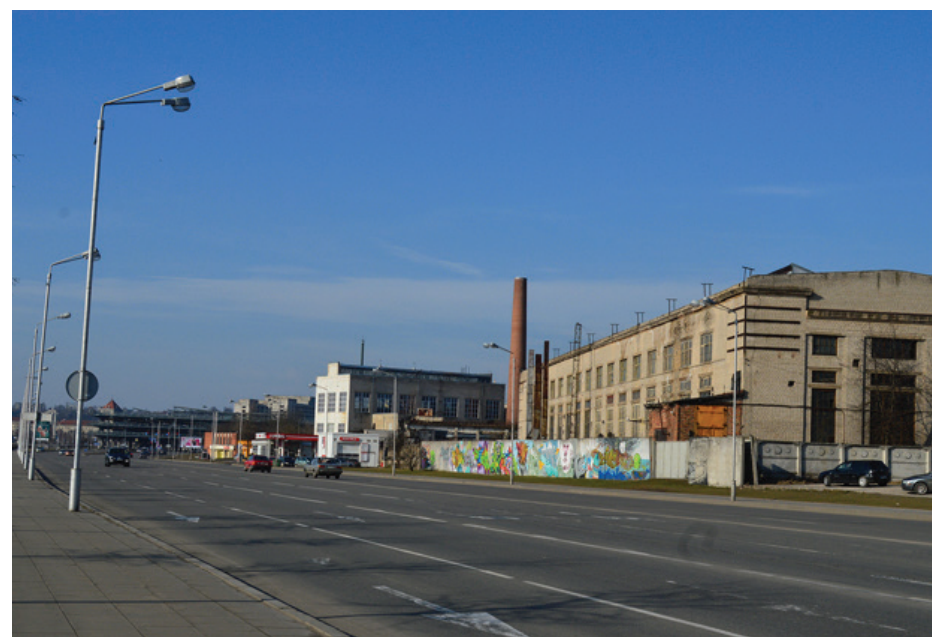

Fig. 9. Untypical streetscape view in city centre. $(D 1=2.1953 ;$ Dlavera$g e=2.2891)$ [Photo: Authors of the Article].

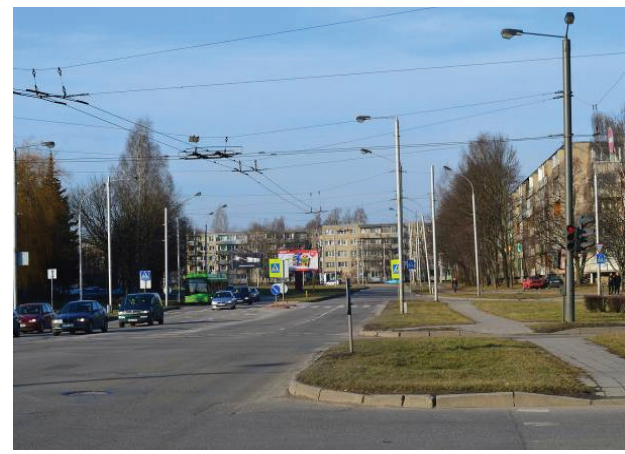

Fig. 11. Typical streetscape view in Dainava area. $(\mathrm{D} 1=2.3660 ;$ D1 average $=2.3842)$ [Photo: Authors of the Article].

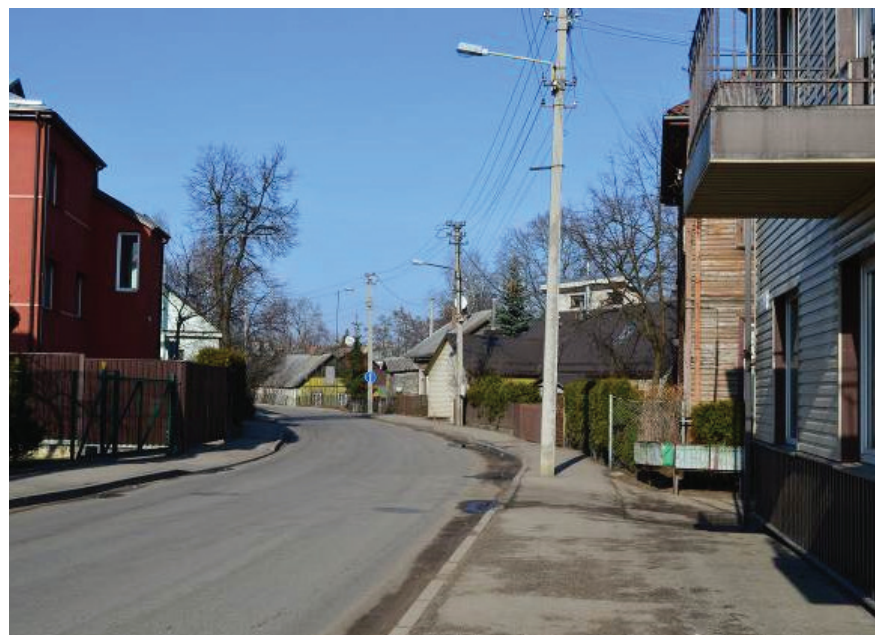

Fig. 10. Typical streetscape view in Zemieji Sanciai. $(D 1=2.3771 ;$ Dlavera $g e=2.3879$ ) [Photo: Authors of the Article].

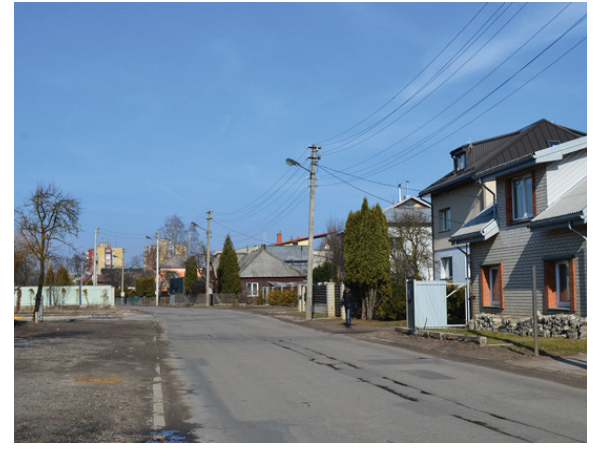

Fig. 12. Typical streetscape in Aukstieji Sanciai. $(\mathrm{D} 1=2.3449$; D1average $=2.3461)[$ Photo: Authors of the Article].

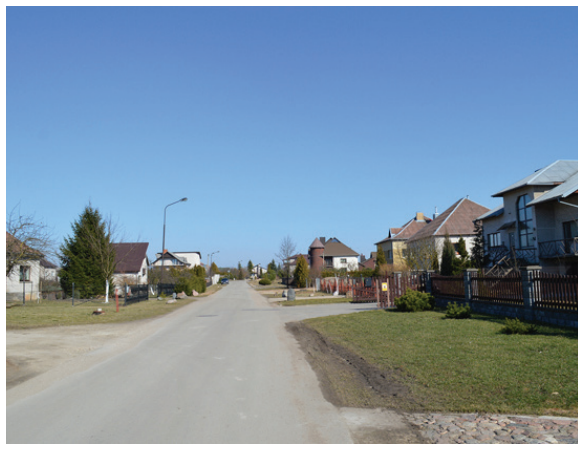

Fig. 13. Typical streetscape view in Rokai district. $(\mathrm{D} 1=2.3057$; D1 average $=2.3057)[$ Photo: Authors of the Article]. open spaces dominate. It was noted that higher fractal dimensions of panoramic views are determined by rich landscaping, further reaching visibility, more heterogenic, various or consistently repetitive architecture and vice versa, the zones with poor landscaping, plainer architecture or empty open spaces distinguish with much lower fractal dimensions.

\section{Fractal Analysis of Streetscape Views}

The average values of fractal dimensions calculated for the streetscape views within different districts are shown in Table III.

Based on the calculated values of fractal dimension, the most typical streetscape views of different districts were selected (see Figs. 7-13, where $D 1$ is fractal dimension of the certain view captured in the photo; Dlaverage is an average value of fractal dimensions in the certain district).

The analysis results (see Table III and Figs. 7-13) revealed that streetscape views of New Town district had the highest fractal dimension. Such a high position was determined by the predominant linear landscaping along the majority of the district's streets. The historical suburb Zemieji Sanciai was not far from New Town by the average value of fractal dimensions. The key factors of that high level of fractal dimension were small urban scale of the territory, quite a big amount of vegetation and prevalent buildings with wooden facades, which created certain textures or patterns and enhanced decorativity and complexity of the view. It was quite unexpected, that the streetscape views of residential districts Dainava and Aukstieji Sanciai, developed in Soviet times, followed New Town and Zemieji Sanciai by the calculated average values of fractal dimensions. The urban morphotype is very different from historical suburbs here. Free planning build up of multi-storey apartment houses is predominant and due to that, there are plenty of open spaces between the single buildings. Since these spaces are rich in vegetation (trees, bushes, grass, etc.), fractal dimension was significantly increased. Streetscape views of Dainava district had higher values of fractal dimension than the ones of Aukstieji Sanciai, as the latter district lacks greenery. Due to a significant lack of vegetation, the streetscape views of Old Town rank only fifth. Actually, just very decorative historical architecture, other heterogeneous surfaces (as stone pavement) and narrow streets allow keeping up with the first four positions with still relatively high level of fractal dimension. Meanwhile, recently developed residential district Rokai occupied lower position because of particularly extensive low-rise building up. Finally, the last place was taken by 
TABLE IV

Average Values and Ranges of D1 (greyscale) Fractal Dimension in Different Areas [Authors of the Article]

\begin{tabular}{|c|c|c|c|c|c|}
\hline \multirow[t]{2}{*}{ Analysed territories } & \multicolumn{2}{|c|}{ Panoramic views } & \multicolumn{2}{|c|}{ Streetscape views } & \multirow{2}{*}{$\begin{array}{l}\text { Key factors and their influence on the value of } \\
\text { fractal dimension }\end{array}$} \\
\hline & D1 & $\mathbf{R}$ & D1 & $\mathbf{R}$ & \\
\hline & 2 & 3 & 4 & 5 & 6 \\
\hline \multicolumn{6}{|l|}{ First rank } \\
\hline $\begin{array}{l}\text { City centre } \\
\text { (Old Town) }\end{array}$ & $\begin{array}{c}\mathbf{2 . 3 4 6 4} \\
(2.3124-2.4100)\end{array}$ & 2 & $\begin{array}{c}\mathbf{2 . 3 7 3 6} \\
(2.3069-2.4542)\end{array}$ & 4 & $\begin{array}{l}\text { + decorative architecture } \\
+ \text { majority of spaces are quite narrow, open } \\
\text { spaces have good proportions } \\
\text { - lack of greenery }\end{array}$ \\
\hline $\begin{array}{l}\text { City centre } \\
\text { (New Town) }\end{array}$ & $\begin{array}{c}\mathbf{2 . 2 5 6 6} \\
(2.2328-2.3579)\end{array}$ & 3 & $\begin{array}{c}\mathbf{2 . 4 3 0 1} \\
(2.2886-2.4929)\end{array}$ & 1 & $\begin{array}{l}\text { + rhythmic and regular pattern of facades } \\
+ \text { open spaces are of rational size } \\
+ \text { greenery along the majority of the streets }\end{array}$ \\
\hline $\begin{array}{l}\text { City centre (untypical } \\
\text { spaces in New Town) }\end{array}$ & $\begin{array}{c}2.1920 \\
(2.1407-2.2311)\end{array}$ & 4 & $\begin{array}{c}\mathbf{2 . 2 8 5 1} \\
(2.2647-2.3063)\end{array}$ & 7 & $\begin{array}{l}\text { - broad sized buildings (Zalgirio arena, Akropolis) } \\
\text { - hypertrophied open spaces } \\
\text { - not very rich in greenery }\end{array}$ \\
\hline \multicolumn{6}{|l|}{ Second rank } \\
\hline $\begin{array}{l}\text { Historic suburbs } \\
\text { (Zemieji Sanciai) }\end{array}$ & not asses & & $\begin{array}{c}\mathbf{2 . 3 8 7 9} \\
(2.2802-2.4594)\end{array}$ & 2 & $\begin{array}{l}+ \text { small pattern of facades } \\
+ \text { narrow streets } \\
+ \text { rich and evenly distributed vegetation }\end{array}$ \\
\hline \multicolumn{6}{|l|}{ Third rank } \\
\hline $\begin{array}{l}\text { Residential areas de- } \\
\text { veloped } \\
\text { in soviet times (Dain- } \\
\text { ava) }\end{array}$ & $\begin{array}{c}\mathbf{2 . 3 7 1 3} \\
(2.2837-2.4320)\end{array}$ & 1 & $\begin{array}{c}\mathbf{2 . 3 8 4 2} \\
(2.3069-2.4612)\end{array}$ & 3 & $\begin{array}{l}\text { + repetitive partition of facades } \\
\text { - wide streets, big open spaces } \\
\text { + very abundant landscaping }\end{array}$ \\
\hline $\begin{array}{l}\text { Residential areas de- } \\
\text { veloped in Soviet times } \\
\text { (Aukstieji Sanciai) }\end{array}$ & not asses & & $\begin{array}{c}\mathbf{2 . 3 4 6 1} \\
(2.2668-2.4310)\end{array}$ & 5 & $\begin{array}{l}\text { - smaller buildings, simpler architecture } \\
+/ \text { - there are both wide and very open spaces and } \\
\text { quite narrow and closed spaces } \\
\text { + rich vegetation }\end{array}$ \\
\hline $\begin{array}{l}\text { Single family housing } \\
\text { areas (Rokai) }\end{array}$ & not asses & & $\begin{array}{c}\mathbf{2 . 3 0 5 7} \\
(2.2445-2.4067)\end{array}$ & 6 & $\begin{array}{l}\text { - monotonous architecture } \\
\text { - especially extensive building up } \\
\text { - lack of vegetation (mostly just internal parcels } \\
\text { landscaping) }\end{array}$ \\
\hline
\end{tabular}

the hypertrophied spaces of New Town (streetscape view of Karaliaus Mindaugo Prospectus), which is untypical for the urban structure of the whole Kaunas city and especially for the central part of it.

To sum up, the general patterns of the certain values were noticeable. Firstly, higher fractal dimensions were calculated for the images where greenery was in the foreground of the streetscape view. Secondly, the smaller partition of planes, more detailed and decorative surfaces and the large variety of them increased the value of fractal dimension. Moreover, the width of the streets was significant. The narrower the street was, the higher fractal dimension was calculated and vice versa. Therefore, the lowest values of fractal dimensions were determined by big open spaces, monotonous and homogenous surfaces - plain facades, high fences, big scale or smooth pavements and the lack of greenery. Finally, all these general findings led to the notion that the fractal dimension of streetscape views allows to reveal the zones with different urban character and with different identity as well.

\section{E. Comparison of Results of Different Fractal Analysis}

Comparison of fractal analysis of panoramic and streetscape views is presented in Table IV.

The results showed, that the values of fractal dimension calculated for the same district correlated to one another if all formants of urban structure (buildings, spaces and greenery) were visible in both panoramic and streetscape views. Fractal dimensions varied depending on the shape and size of these formants and the position in relation to each other. Such multifactorial influence means, that the same or very close fractal dimensions could be calculated for two views even if their urban morphotype is quite different (see Figs. 14-15). Therefore, the value of fractal dimension alone does not allow making conclusions without comparing these results with analysed views. 


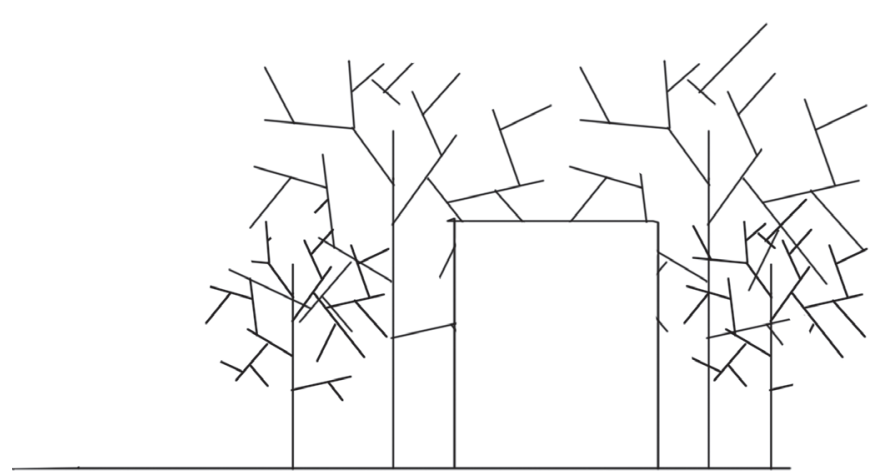

Fig. 14. Graphical models of two different streetscape views with the same fractal dimension $(\mathrm{D}=1.1132)$. Model 1 [Photo: Authors of the Article].

\section{F. Comparison of Fractal Analysis Results with Other Studies}

During the analysis of planar structure of the city, it is possible to extract separate formants of urban structure (buildings, spaces and greenery) from the whole and to calculate fractal dimensions for each of them individually [18].

The results of fractal analysis of panoramic and streetscape views in zones with different semantic loads were compared with the results [18] of the fractal analysis of buildings and greenery in the same zones. It showed that the highest fractal dimensions were calculated for the New Town during both planar and views analyses. The lowest fractal dimensions were derived for recently developed single-family housing areas during both studies as well. There were some small differences between the intermediate values. These differences occurred, because it is not possible to perceive the overall urban structure completely via the streetscape or panoramic views. Just some fragments of the whole system are visible. Moreover, such green areas as meadows, grass fields or lawns, which can play quite an important role in planar structure, are much less significant in streetscape or panoramic views. Thus, we see that different approaches of the same method can reveal different aspects of urban structure.

\section{Conclusion}

In this research, three ranges of zones with different semantic load were designated in Kaunas. Later on, fractal dimensions of images from these different zones were calculated. Districts with different character got different values of fractal dimension. However, not always higher fractal dimension meant higher semantic load but it clearly represented the nature of city identity formants. Firstly, the greenery plays a very significant role in increasing fractal dimension. However, the abundance of vegetation hides the character of the man-created urban structure. Thus, if there is no vegetation in the view, it is possible to evaluate the character and architectural expression of buildings themselves

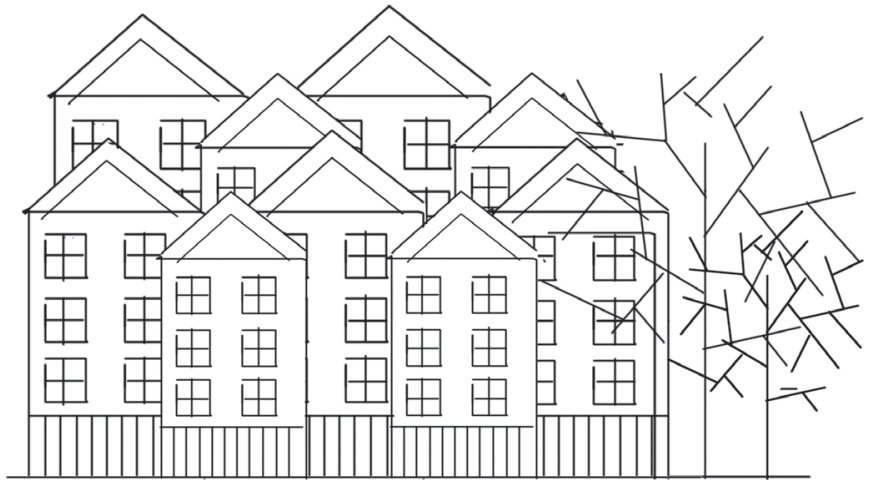

Fig. 15. Graphical models of two different streetscape views with the same fractal dimension $(\mathrm{D}=1.1132)$. Model 2 [Photo: Authors of the Article].

and the spaces around. In such case, low fractal dimensions indicate monotonic buildings with plain facades, smooth pavements, fences or other surfaces and big open empty spaces. The high value of fractal dymensions shows that there is a variety of buildings with decorative facades, strongly textured pavements, filigree fences and narrow or very fragmented spaces. Besides, there are differences in fractal dimensions of the views depending on the weather conditions, lighting angle, view depth or the season of the year. In the ideal case, all these conditions should be the same for the assessment. Moreover, the comparison of this research with another research, where the planar urban structure was analysed using fractal analysis, showed, that different methods could reveal different aspects of the urban structure.

To conclude, the research confirmed that fractal analysis can be one of the tools for quantitative assessment of cityscape identity and fractal analysis of different views and scales (e.g., analysis of streetscape views, analysis of panoramic views, analysis of planar structure, etc.) should be combined together to reach the best and most comprehensive results. In order to reveal the holistic cityscape identity, both qualitative and quantitative assessments should be integrated.

\section{AcKnOwLedgment}

The authors wish to thank Hiroyuki Sasaki and the personnel of Incorporated Administrative Agency NARO for allowing to use "Fractal Analysis System" software.

\section{REFERENCES}

1. The Athens Charter. Congress Internationaux d'Architecture moderne (CIAM) (Translated by J. Tyrwhitt, 1946), 1933, Paris, France.

2. International Charter for the Conservation and Restoration of Monuments and Sites (The Venice Charter 1964) [online]. ICOMOS [cited 03.05.2017]. https://www.icomos.org/charters/venice_e.pdf

3. Convention Concerning the Protection of the World Cultural and Natural Heritage, 1972. [online]. UNESCO [cited 05.05.2017]. https://whc.unesco. org/archive/convention-en.pdf 
4. Towards a Thematic Strategy on the Urban Environment, 2004 [online] Commission of the European Communities [cited 03.05.2017]. https://eurlex.europa.eu/legal-content/EN/TXT/PDF/?uri=CELEX:52004DC0060\&from $=\mathrm{EN}$

5. Renewed EU Sustainable Development Strategy, 2006 [online]. Council of the European Union [cited 03.05.2017]. http://register.consilium.europa. $\mathrm{eu} / \mathrm{doc} / \mathrm{srv} ? \mathrm{l}=\mathrm{EN} \& \mathrm{f}=\mathrm{ST} \% 2010117 \% 202006 \% 20 \mathrm{INIT}$

6. Leipzig Charter on Sustainable European Cities, 2007 [online]. European Commission [cited 04.05.2017]. https://ec.europa.eu/regional_policy/ archive/themes/urban/leipzig_charter.pdf

7. Osborne, B. S. Landscapes, Memory, Monuments, and Commemoration: Putting Identity in Its Place. Canadian Ethnic Studies, 2001, Vol. 33, Issue 3, pp. 39-77.

8. Povilaitienè, I., Kamičaitytè-Virbašienė, J. Theoretical Premises of Cityscape Identity Evaluation. CITTA 8th Annual Conference on Planning Research: Book of proceedings, 2015, pp. 381-401.

9. Cooper, J. Fractal Assessment of Street Level Skylines: A Possible Mean of Assessing and Comparing Character. Urban Morphology, 2003, Vol. 7 , Issue 2, pp. 73-82.

10. Cooper, J., Oskrochi, R. Fractal Analysis of Street Vistas: A Potential Tool for Assessing Levels of Visual Variety in Everyday Street Scenes. Environment and Planning B: Planning and Design, 2008, Vol. 35, pp. 349-363. https://doi.org/10.1068/b33081

11. Cole, M. Cultural Psychology: A Once and Future Discipline. Cambridge, MA: The Belknap Press of Harvard University Press, 1998. 416 p.

12. Zaleckis, K., Kamičaitytė-Virbašienė, J., Ramanauskas, E. Preservation of Kaunas City Identity while Planning its Urban Development Ecological architecture 2013: Book of Abstracts, 2013, p. 32.

13. Batty, M., Longley, P. Fractal Cities: A Geometry of Form and Function. London: Academic Press, 1994. 394 p.

14. Salingaros, N. A. Principles of Urban Structure. Amsterdam: Techne Press, 2005. $252 \mathrm{p}$

15. Salingaros, N. A. The Laws of Architecture from a Physicist's Perspective. Physics Essays, 1995, Vol. 8, Issue 4, pp. 638-643.

16. Salingaros, N. A. A Theory of Architecture. Solingen: Nikos A. Salingaros \& Umbau-Verlag, 2006. 278 p.

17. Hillier, B. Space is the Machine: A Configurational Theory of Architecture. Cambridge: Cambridge University Press, $1999.370 \mathrm{p}$

18. Zaleckis, K., Kamičaitytè-Virbašienė, J. Urbanistinių struktūrų potencialo vertinimas: Kauno centras miesto visumos kontekste [Evaluating the Potential of Urban Structures: Kaunas case]. Town Planning and Archtecture, 2011, Vol. 35, Issue 4, pp. 249-259. https://doi.org/10.3846/tpa.2011.26

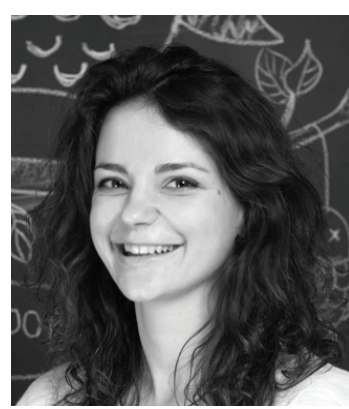

Ingrida Povilaitienè received the degree of Bachelor of Architecture in 2011, and the de gree of Master of Land Management in 2013. 2011-2014 she was an architect with the Centre of Territory Planning of the KTU Institute of Architecture and Construction. Since 2014, she has proceeded her doctoral studies at Kaunas University of Technology. Her main research interests are urban identity, relationship between human beings and their environment (landscape/cityscape), sustainable development and preferred environment.

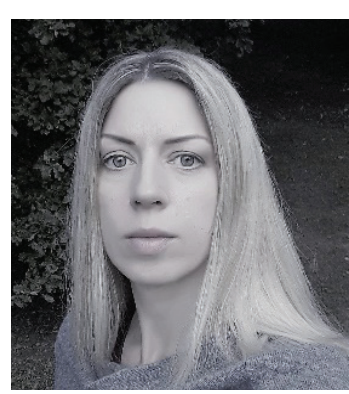

Jūratė Kamičaitytė-Virbašienė received the degree of Bachelor of Architecture in 1997, the degree of Master of Architecture in 1999, and the degree of Doctor of Technological Sciences in 2003. She is currently a Professor of the Faculty of Civil Engineering and Architecture of Kaunas University of Technology. Herhe main research interests are landscape visual quality analysis, evaluation and regulation; methods of visual impact assessment; analysis of public preferences evaluating landscape and use of the analysis results in spatial planning; evaluation of the potential of urban structures; townscape identity studies; sustainable development in architecture, town and territory planning and landscape architecture.

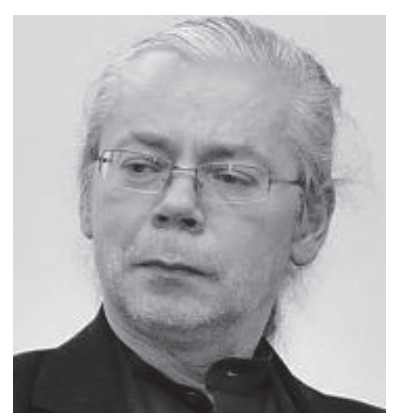

Kęstutis Zaleckis (b. Kaunas, 1969) obtained the Diploma in Architecture in 1992 from Vilnius Gediminas Technical University, and the degree of Doctor of Humanities in 2002 from Vytautas Magnus University/ Institute of Architecture and Construction. $\mathrm{He}$ is currently a Professor of the Faculty of Civil Engineering and Architecture of Kaunas University of Technology. His research interests are evolution and mutations of urban spatial genotypes, relations between spatial urban configurations and its social content, urban history.

Contact Data

Ingrida Povilaitienė

Kaunas University of Technology, Faculty of Civil Engineering and Architecture,

Address: 48 Studentu St., Kaunas, 51367, Lithuania

E-mail: ingrida.povilaitiene@ktu.edu

\section{Jūratė Kamičaitytė-Virbašienè}

Kaunas University of Technology, Faculty of Civil Engineering and Architecture,

Address: 48 Studentu St., Kaunas, 51367, Lithuania

E-mail: jurate.kamicaityte@ktu.lt

\section{Kęstutis Zaleckis}

Kaunas University of Technology, Faculty of Civil Engineering and Architecture,

Address: 48 Studentu St., Kaunas, 51367, Lithuania

E-mail: kestutis.zaleckis@ktu.lt 